\title{
Detection of cytomegalovirus using PCR in serum from renal transplant recipients
}

\author{
R Cunningham, A Harris, A Frankton, W Irving
}

\begin{abstract}
Aims-To develop a polymerase chain reaction (PCR) assay for the detection of cytomegalovirus (CMV) DNA in serum and leucocytes of renal transplant recipients and compare this assay with CMV culture and serodiagnosis.

Methods-Monthly specimens were obtained from 12 patients starting immediately before transplant. CMV infection was monitored by IgM enzyme linked immunosorbent assay, virus culture and PCR on serum and leucocytes.

Results-Two of four IgG positive patients had reactivation of $\mathrm{CMV}$ disease confirmed by culture, three of eight seronegative patients had a primary infection, one confirmed by serology and two by culture. PCR was positive earlier than conventional methods in three cases and concurrently in two. No positive PCR reactions occurred in the seven patients who remained negative by culture and serology. Conclusions-CMV DNA is detectable in serum; serum may be positive before virus is detectable by buffy coat culture; and PCR may be useful as an early indication of potential CMV disease in renal transplant recipients.
\end{abstract}

(f Clin Pathol 1995;48:575-577)

Microbiology and

Public Health

Laboratory, University

Hospital, Queen's

Medical Centre,

Nottingham NG7 2UH

$\mathrm{R}$ Cunningham

A Harris

W Irving

Renal Unit,

City Hospital,

A Frankton

Correspondence to:

Dr R Cunningham.

3 November 1994

Cytomegalovirus (CMV) infection is an important cause of morbidity in immunocompromised patients. Management of this condition is complicated by the toxicity of currently available treatments (ganciclovir and foscarnet), and the relative slowness and insensitivity of currently available diagnostic tests. ${ }^{1}$ Virus culture methods with detection of "early" antigen by immunofluorescence is sensitive and specific, but is laborious and unsuitable for routine processing of large numbers of specimens. Serological diagnosis of infection
Department of

Nottingham NG5 1PB

Accepted for publication:

is unreliable in immunocompromised patients and may not be rapid enough to permit early treatment. $^{2}$ The polymerase chain reaction (PCR) has been shown to be useful in the diagnosis of active CMV infection of the central nervous system in patients with AIDS, and also in monitoring patients post-transplantation to identify those at high risk of $\mathrm{CMV}$ disease before antigenaemia becomes detectable. ${ }^{34} \mathrm{~A}$ recent study reported detection of CMV DNA in serum of patients during primary and congenital infection. ${ }^{5}$ We hypothesised that active infection may be associated with release of viral DNA into serum and therefore have assessed the value of the PCR assay using serum samples from a group of well characterised renal transplant recipients in comparison with PCR amplification of DNA extracted from circulating leucocytes, CMV culture and serology.

\section{Methods}

Twelve patients (four men and eight women) with a mean age of 51 years (range 35 to 71 years) undergoing renal transplantation were studied. Four were positive for IgG to CMV at the time of transplantation. Patients were treated with a standard regimen of prednisolone, cyclosporin and azathioprine. Informed consent was obtained from all patients and the study was approved by the hospital ethics committee. Patient details are summarised in table 1 .

Table 1 Patient details

\begin{tabular}{lllll}
\hline Patient & Sex & Age (years) & Patient CMV status & Donor CMV status \\
\hline A & F & 38 & Negative & Positive \\
B & F & 35 & Negative & Positive \\
C & F & 65 & Negative & Positive \\
D & M & 57 & Positive & Negative \\
E & F & 71 & Positive & Positive \\
F & F & 39 & Pegative & Negative \\
G & F & 36 & Positive & Negative \\
H & M & 67 & Negative & Negative \\
I & F & 39 & Negative & Negative \\
J & F & 36 & Negative & Negative \\
L & M & 45 & Negative & \\
\hline
\end{tabular}

\section{SPECIMENS}

Blood samples were taken immediately before transplantation in 11 patients and at approximately monthly intervals thereafter. In one patient the first sample was collected 18 days post-transplant. Specimens were transported to the laboratory using the normal hospital transport system. Whole blood was stored using the "Glycigel" method and frozen at $-70^{\circ}$ until DNA extraction. ${ }^{6}$ Serum samples were stored at $-20^{\circ} \mathrm{C}$ until serological testing and DNA extraction.

SEROLOGICAL TESTING

Sera were tested using a standard complement fixation method, ${ }^{7}$ and anti-CMV IgG and IgM enzyme linked immunosorbent assays (CAPTIA, Mercia diagnostics, Camberley, Surrey, UK).

\section{CULTURE}

Leucocytes from heparinised blood were inoculated in duplicate in MRC5 cell cultures. 
These were incubated for 28 days and examined twice weekly for cytopathic effects with a change of medium after each examination.

\section{DNA EXTRACTION FROM SERUM}

DNA was extracted from $400 \mu \mathrm{l}$ aliquots of serum. These were made up to $1 \mathrm{ml}$ with distilled water, then $500 \mu \mathrm{l}$ of $30 \%$ polyethyleneglycol 8000 in $0.1 \mathrm{M} \mathrm{NaCl}$ was added and the precipitate centrifuged after holding on ice for 60 minutes. The supernatant was discarded and the pellet resuspended in $300 \mu \mathrm{l}$ Tris-EDTA extraction buffer, $(10 \mathrm{mM}$ Tris- $\mathrm{HCl}, \mathrm{pH} 7,1 \mathrm{mM}$ EDTA). Sodium dodecylsulphate $(10 \% ; 40 \mu \mathrm{l})$ and $300 \mu$ l equilibrated phenol ( $\mathrm{pH} 7 \cdot 5)$ were added and the mixture centrifuged at $13000 \mathrm{rpm}$ for $10 \mathrm{~min}$ utes. The aqueous phase was mixed with $30 \mu \mathrm{l}$ $3 \mathrm{M}$ sodium acetate, $1 \mu \mathrm{l}$ glycogen and $1 \mathrm{ml}$ absolute ethanol. The DNA was precipitated overnight at $-70^{\circ} \mathrm{C}$ and the ethanol discarded after centrifuging the nucleic acid at $13000 \mathrm{rpm}$ for 15 minutes. The pellet was resuspended in $30 \mu \mathrm{l}$ distilled water and stored at $-70^{\circ} \mathrm{C}$ until tested.

\section{DNA EXTRACTION FROM LEUCOCYTES}

"Glycigel" preserved whole blood was melted in a $37^{\circ} \mathrm{C}$ waterbath and a $1 \mathrm{ml}$ aliquot centrifuged at $14000 \mathrm{rpm}$ for one minute. The top $0.5 \mathrm{ml}$ was discarded and $0.5 \mathrm{ml}$ lysis buffer (10 mM Tris- $\mathrm{HCl}, \mathrm{pH} 7 \cdot 5,1 \%$ Triton X100, $0.32 \mathrm{M} \mathrm{MgCl}_{2}$ ) added. This was centrifuged at $14000 \mathrm{rpm}$ for 20 seconds and the cell nucleus pellet washed twice with $1.0 \mathrm{ml}$ lysis buffer. The pellet was resuspended in $100 \mu$ l extraction buffer ( $10 \mathrm{mM}$ Tris- $\mathrm{HCl}, \mathrm{pH} 8 \cdot 3,50 \mathrm{mM} \mathrm{KCl}$, $2.5 \mathrm{mM} \mathrm{MgCl}_{2}, 0.001 \%$ gelatin, $0.45 \%$ Tween $20,0.45 \%$ Nonidet P40) and $0.6 \mu \mathrm{l} 10 \mathrm{mg} /$ $\mathrm{ml}$ proteinase $\mathrm{K}$. This was heated in a $60 \%$

Table 2 Culture, serology and PCR on serum and leucocytes of 12 renal transplant recipients

\begin{tabular}{|c|c|c|c|c|c|c|}
\hline $\begin{array}{l}\text { Patient A } \\
\text { culture } \\
\text { PCR (cells) } \\
\text { PCR (serum) } \\
\text { CFT titre } \\
\text { IgM }\end{array}$ & $\begin{array}{l}\text { Day } 0 \\
- \\
- \\
- \\
<16 \\
-\end{array}$ & $\begin{array}{l}\text { Day } 27 \\
- \\
- \\
- \\
<16 \\
-\end{array}$ & $\begin{array}{l}\text { Day } 76 \\
- \\
+ \\
+ \\
>256 \\
+\end{array}$ & $\begin{array}{l}\text { Day } 79 \\
+ \\
+ \\
+ \\
>256 \\
\text { ND }\end{array}$ & $\begin{array}{l}\text { Day } 92 \\
+ \\
+ \\
+ \\
>256 \\
\text { ND }\end{array}$ & $\begin{array}{l}\text { Day } 120 \\
+ \\
+ \\
+ \\
>256 \\
+\end{array}$ \\
\hline $\begin{array}{l}\text { Patient B } \\
\text { culture } \\
\text { PCR (cells) } \\
\text { PCR (serum) } \\
\text { CFT titre } \\
\text { IgM }\end{array}$ & $\begin{array}{l}\text { Day } 0 \\
- \\
\text { ND } \\
- \\
<16 \\
-\end{array}$ & $\begin{array}{l}\text { Day } 31 \\
\text { ND } \\
+ \\
+ \\
64 \\
+\end{array}$ & $\begin{array}{l}\text { Day } 56 \\
- \\
+ \\
+ \\
>256 \\
+\end{array}$ & $\begin{array}{l}\text { Day } 94 \\
- \\
- \\
- \\
>256 \\
+\end{array}$ & $\begin{array}{l}\text { Day } 128 \\
- \\
- \\
- \\
>256 \\
+\end{array}$ & \\
\hline $\begin{array}{l}\text { Patient C } \\
\text { culture } \\
\text { PCR (cells) } \\
\text { PCR (serum) } \\
\text { CFT titre } \\
\text { IgM }\end{array}$ & $\begin{array}{l}\text { Day } 0 \\
- \\
\text { ND } \\
- \\
<16 \\
-\end{array}$ & $\begin{array}{l}\text { Day } 26 \\
- \\
\text { ND } \\
- \\
<16 \\
-\end{array}$ & $\begin{array}{l}\text { Day } 54 \\
- \\
\text { ND } \\
+ \\
512 \\
+\end{array}$ & $\begin{array}{l}\text { Day } 70 \\
- \\
\text { ND } \\
+ \\
>2048 \\
+\end{array}$ & $\begin{array}{l}\text { Day } 92 \\
+ \\
\text { ND } \\
+ \\
>2048 \\
+\end{array}$ & $\begin{array}{l}\text { Day } 225 \\
- \\
\text { ND } \\
+ \\
\text { ND } \\
\text { ND }\end{array}$ \\
\hline $\begin{array}{l}\text { Patient D } \\
\text { culture } \\
\text { PCR (cells) } \\
\text { PCR (serum) } \\
\text { CFT titre } \\
\text { IgM }\end{array}$ & $\begin{array}{l}\text { Day } 18 \\
- \\
\text { ND } \\
+ \\
64 \\
-\end{array}$ & $\begin{array}{l}\text { Day } 32 \\
+ \\
\text { ND } \\
+ \\
64 \\
-\end{array}$ & $\begin{array}{l}\text { Day } 60 \\
+ \\
+ \\
+ \\
>256 \\
-\end{array}$ & $\begin{array}{l}\text { Day } 90 \\
- \\
- \\
- \\
>256 \\
\text { ND }\end{array}$ & $\begin{array}{l}\text { Day } 118 \\
- \\
\text { ND } \\
- \\
>256 \\
-\end{array}$ & $\begin{array}{l}\text { Day } 167 \\
- \\
\text { ND } \\
+ \\
\text { ND } \\
\text { ND }\end{array}$ \\
\hline $\begin{array}{l}\text { Patient E } \\
\text { culture } \\
\text { PCR (cells) } \\
\text { PCR (serum) } \\
\text { CFT titre } \\
\text { IgM }\end{array}$ & $\begin{array}{l}\text { Day } 0 \\
\text { ND } \\
- \\
- \\
<16 \\
-\end{array}$ & $\begin{array}{l}\text { Day } 19 \\
+ \\
+ \\
+ \\
64 \\
+1-\end{array}$ & $\begin{array}{l}\text { Day } 28 \\
+ \\
+ \\
+ \\
64 \\
+1-\end{array}$ & $\begin{array}{l}\text { Day } 89 \\
+ \\
+ \\
+ \\
>25 \\
\text { ND }\end{array}$ & $\begin{array}{l}\text { Day } 105 \\
+ \\
+ \\
- \\
>256 \\
\text { ND }\end{array}$ & $\begin{array}{l}\text { Day } 131 \\
\text { ND } \\
+ \\
\text { ND } \\
>256 \\
\text { ND }\end{array}$ \\
\hline
\end{tabular}

CFT $=$ complement fixation test. waterbath for two hours and then the proteinase $\mathrm{K}$ was denatured by heating to $95^{\circ} \mathrm{C}$ for 10 minutes. The extract was stored at $-70^{\circ} \mathrm{C}$ until processed.

\section{PCR ASSAY}

CMV DNA was detected by nested PCR, using primers associated with the glycoprotein $\mathbf{B}$ gene: primer 1 ( $5^{\prime}$ GAGGACAACGAAATCCTGTTGGGCA 3'); primer 2 (5' GTCGACGGTGGAGATACTGCTGAGG 3'); primer 3 (5' ACCACCGCACTGAGGAATGTCAG $\left.3^{\prime}\right)$; and primer 4 (5' TCAATCATGCGTTTGAAG-AGGTA $\left.3^{\prime}\right) .{ }^{8}$ Primers 1 and 2 were used in the first round of the assay and produced a 150 base pair fragment. The second round produced a 100 base pair fragment. Each $50 \mu \mathrm{l}$ reaction mixture contained $5 \mu \mathrm{l}$ target DNA, $100 \mathrm{ng}$ of each primer, $0.4 \mu \mathrm{l}$ deoxynucleoside triphosphate stock (containing $25 \mathrm{mM}$ dATP, dCTP, dGTP, and dTTP) and 1 unit of Taq polymerase (Perkin Elmer Cetus, Norwalk, California, USA).

The first round comprised a denaturation cycle of seven minutes at $95^{\circ}$ followed by 25 cycles of denaturation at $95^{\circ} \mathrm{C}$ for one minute, annealing at $55^{\circ} \mathrm{C}$ for one minute, extension at $72^{\circ} \mathrm{C}$ for one minute with a final seven minutes at $72^{\circ} \mathrm{C}$. The second round used $1 \mu \mathrm{l}$ of first round product as the template; annealing was performed at $40^{\circ} \mathrm{C}$ for one minute, otherwise conditions were the same as in the first round.

The amplified product was visualised on a $2 \%$ agarose gel containing $500 \mathrm{ng} / \mathrm{ml}$ ethidium bromide and illuminated under ultraviolet light. Positive and negative controls were included in each amplification, as was a buffer control. We followed the guidelines suggested by Kwok and Higuchi to avoid contamination. ${ }^{9}$

\section{Results}

PRIMARY INFECTIONS

There were three primary infections in the course of this study. One was detected by positive CMV IgM from samples taken at 31 days post-transplant. The other two were detected by culture from samples taken at 79 and 92 days post-transplant. PCR was positive on serum and cells from samples taken at 31,76 and 54 days - that is, concurrently or significantly earlier.

\section{SECONDARY INFECTIONS}

There were two infections in patients seropositive at the time of transplantation. These were detected by positive CMV culture from samples taken at 28 and 32 days post-transplant. PCR was positive on serum and cells of the first patient from samples taken at 19 days. Cells were not available for the second patient but serum PCR was positive from samples taken at 18 days.

\section{PATIENTS WITH NO EVIDENCE OF CMV} INFECTION

Seven patients remained CMV antibody and culture negative. None of the 42 serum samples 
from these patients were positive by PCR. Cellular DNA was available from four patients. None of the 22 specimens was positive by PCR. Full results are given in table 2 .

\section{Discussion}

Diagnosis of CMV infection by PCR is rapid, sensitive and specific when performed on DNA extracted from infected leucocytes. This has been applied to various groups of immunocompromised patients-for example, renal transplant, bone marrow transplant, leukaemia, and lymphoma. ${ }^{10} \mathrm{~A}$ problem with this technique is that it may detect latent CMV DNA in seropositive patients in the absence of clinical disease. In 19 of 20 immunosuppressed patients leucocytes were positive by PCR up to 16 weeks after culture/immunofluorescence became negative. ${ }^{11}$ Another study looked at healthy blood donors and detected CMV DNA in peripheral mononuclear cells from 25 of 30. ${ }^{12}$

It is reasonable to hypothesise that active viral replication may lead to release of virus from cells into serum. However, few studies have been published on the detection of CMV DNA in serum. In one study CMV DNA was detected in serum of leukaemic patients with CMV pneumonia. As in the present study, they found that serum samples from 16 asymptomatic subjects were negative by PCR, including samples from those who were CMV seropositive. ${ }^{13}$ In a mixed group of patients with primary infection CMV DNA was detected in serum before CMV specific IgM in 13 of 44 cases. A study of 19 AIDS patients with intracerebral CMV infection at necropsy found that 12 of 13 serum samples contained CMV DNA whereas only one of 10 serum samples from HIV positive patients without CMV disease was positive. None of 10 samples from HIV negative patients without evidence of $\mathrm{CMV}$ infection was positive. ${ }^{3}$

Serum has a number of advantages over separated leucocytes for the detection of viruses using PCR. It is one of the commonest specimens sent to virology laboratories, it requires very little preparation before DNA extraction and retrospective banks of serum samples are readily available for validation of the test in different patient groups.

We have demonstrated that detection of CMV in serum using PCR is positive at least as early as, and often much earlier than, culture. As we collected specimens at about four weekly intervals, we cannot define the lead time between PCR positivity and diagnosis by conventional methods. We hypothesise that finding CMV DNA in serum may be a stronger indication of active infection than detecting it in leucocytes of seropositive patients, although the number of patients in this study was insufficient to resolve this question.

In conclusion, we suggest that PCR detection of CMV in serum is a sensitive, specific and early indicator of both primary and reactivation infections in renal transplant recipients. Further studies are needed to determine its prognostic value in the various groups of patients at risk of end organ CMV disease. We thank Drs Morgan and Burden of the Renal Unit, City
Hospital, Nottingham, for allowing us to include their patients in this study.

1 Zurlo JJ, O'Neill D, Polis MA, Manischewitz J, Yarchoan R, Baseler $M$, et al. Lack of clinical utility of cytomegalovirus blood and urine cultures in patients with HIV infection. Ann Intern Med 1993;188:12-17.

2 Rice PS, Kudesia G, Price C, Smith GH. Diagnosis of cytomegalovirus infection in heart transplant recipients. $\mathcal{f}$ Clin Pathol 1992;45:636-7.

3 Cinque P, Vago L, Brytting M, Castagna A, Accordini A, Sundqvist V, et al. Cytomegalovirus infection of the centra nervous system in patients with AIDS: Diagnosis by DNA amplification from cerebrospinal fluid. $\mathcal{f}$ Infect Dis 1992 ; 166:1408-11.

4 Prosh S, Kimel V, Dawydowa I, Kruger DH. Monitoring of patients for cytomegalovirus after organ transplantation by centrifugation culture and PCR. F Med Virol 1992;38: 246-51

5 Brytting M, Xu W, Wahren B, Sundqvist V. Cytomegalovirus DNA detection in sera from patients with active cytomegalovirus infections. $\mathcal{F}$ Clin Microbiol 1992;30:1937-41.

6 Kaye S, Loveday C, Tedder RS. Storage and preservation of whole blood samples for use in detection of Human Immunodeficiency Virus type 1 by the polymerase chain reaction. F Virol Methods 1991;35:217-26.

7 Bradstreet CMP, Taylor CED. Month Bull Min Hlth \& PHLS 1962;21:96.

8 Wakefield AJ, Fox JD, Sawyer AM, Taylor JE, Sweenie $\mathrm{CH}$, Smith $M$, et al. Detection of herpesvirus DNA in the large intestine of patients with ulcerative colitis and Crohn's disease using the nested polymerase chain reaction. $f \mathrm{Med}$ Virol 1992;38:183-90.

9 Kwok S, Higuchi R. Avoiding false positives with PCR. Nature 1989;339:237-8.

$10 \mathrm{Xu} \mathrm{W}$, Sundqvist V, Brytting $\mathrm{M}$, Linde A. Diagnosis of cytomegalovirus infections using polymerase chain reaction, virus isolation and serology. Scand 7 Infect Dis 1993;25:311-16.

11 Ratnamohan VM, Mathys JM, McKenzie A, Cunningham AL. HCMV-DNA is detected more frequently than infectious virus in blood leukocytes of immunocompromised patients: A direct comparison of culture-immunopatients: A direct comparison of culture-immunofluorescence and PCR for detection of $\mathrm{HC}$
specimens. $\mp$ Med Virol 1992;38:252-9.

12 Stanier P, Taylor D, Kitchen A, Wales N, Tryhorn Y, Stanley Tims A. Persistence of cytomegalovirus in mononuclear cells in peripheral blood from blood donors. BMf 1989 299:897-8.

13 Ishigaki S, Takeda M, Kura T, Ban N, Saitoh T, Sakamaki $S$, et al. Cytomegalovirus DNA in the sera of patients with cytomegalovirus pneumonia. Br f Haematol 1991;79: 198-204. 